\title{
Enunciação, auto-referencialidade e incompletude
}

\begin{abstract}
RESUMO
Reflete-se sobre as transformações da enunciação jornalística a partir do impacto nela provocado pela passagem da 'sociedade dos meios' para 'sociedade midiatizada'. Examina-se mudanças das marcas de uma 'enunciação representacional' para uma 'enunciação de auto-referenciação' midiática, mostrandose, a partir de 'tipologia' de fragmentos discursivos jornalísticos, a permanência, numa e noutra, da incompletude de sentidos.
\end{abstract}

\section{PALAVRAS-CHAVE}

- midiatização

- enunciação

- discursos jornalísticos

\section{ABSTRACT}

Transformations in the journalistic enunciate are being considered based on the impact caused by the 'society of means' passage to the 'midiatic society'. It is examined the changes of marks of a 'representative enunciation' to a 'enunciation of midiatic self-referece' starting from 'typology' of journalistic discursive fragments, the permanence, in either one the issue regarding the incompleteness of the senses.

\section{KEY WORDS}

- midiatization

- enunciation

- journalistic speeches

\section{Antônio Fausto Neto UNISINOS}

A intensificação dos processos de midiatização, enquanto novas formas tecnológicas de vida ${ }^{1}$ afeta o funcionamento de práticas dos diferentes campos sociais e seus processos de interação, que levam em conta a existência da cultura e de operações midiáticas. No contexto latino-americano ${ }^{2}$, ou mesmo brasileiro, temos refletido sobre tais ocorrências junto às práticas discursivas de vários campos (política, educação, religioso, saúde) e que se manifestam através de complexas apropriações de operações midiáticas, redesenhando suas gramáticas e suas estratégias de reconhecimento ${ }^{3}$.

Para fins deste trabalho, examinaremos aspectos destas manifestações sobre a enunciação jornalística, reformulando e reconfigurando os 'modos de dizer' e o trabalho de produção de referência desta modalidade de discurso. Partimos da hipótese segundo a qual a midiatização se inscreve também através de formas de linguagens, segundo operações que reformulam o lugar de 'interpretante' dos discursos jornalísticos. A intensificação dos processos de autonomia do campo dos mídias, da sua cultura e suas operações, se expande sobre regimes discursivos dos demais campos, produzindo complexa mudança sobre a natureza do próprio trabalho codificador das práticas discursivas jornalísticas. Convertido numa espécie de 'sistema autônomo', cujas operações dependem largamente de sua própria competência tecno-simbólica, o jornalismo desenvolve, hoje, nova forma de contato, segundo "contratos de leituras" assentados em operações de auto-referencialidades. Ou seja, fala cada vez mais para o âmbito público de suas próprias operações, enquanto regras privadas de realidade de construção do que, necessariamente, da construção da realida$\mathrm{de}^{4}$. Ou seja, produz a 'enunciação da enunciação'.

Examinar esta problemática significa fazê-la a partir da leitura das próprias manifestações discursivas jornalísticas, tensionando-as segundo a categoria da enunciação, na medida em que uma prática discursiva se realiza, sempre, através de determinado trabalho enunciativo. Nessas condições, não poderiam estar ausentes destes comentários duas perspectivas que levam em conta a linguagem como instância para construção discursiva e sobre as quais se nutrem as convicções jornalísticas para a produção do seu 'trabalho interpretativo'. De um lado, a linguagem enquanto dimensão 'instrumental', e que segundo nosso ponto de vista, continua guiando a postura jornalística sobre sua concepção de prática discursiva. De outro, a perspectiva 'construcionista', que ao definir a linguagem de um ponto de vista analítico, enfatiza a importância do seu papel constituinte como elemento vital para construir as operações enunciativas que vão engendrar as manifestações discursivas. 


\section{Instrumentalismo x Construcionismo}

Grosso modo, como se distinguiriam estas duas dimensões, atribuídas ao status da linguagem?

\section{A supremacia do 'sujeito falante'}

Estruturado em torno de fundamentos consciencialistas, o ponto de vista instrumental subsidia a enunciação jornalística, enfatizando o papel central do 'sujeito falante'. Atribui-se à linguagem uma 'atividade secundária'. Ou seja, apesar do discurso resultar de uma intensa atividade de 'transação de falas', a linguagem aparece como um 'instrumento'. E o discurso, como produto naturalizado. A linguagem estaria apenas a serviço do 'ato de fala', sendo que este independeria totalmente das injunções que ela produziria como elemento propulsor de sua constituição. Seria uma espécie de 'insumo' restrito à esfera da manobra que sobre ela realizaria, apenas de modo consciencial, o próprio sujeito. Residiria a convicção de que a transmissão da mensagem asseguraria, nas suas próprias fronteiras, as possibilidades de produção de sentidos. Ou seja, toda a expressão do dito estaria contida nos limites e sobre o controle de um dispositivo previsional. A apropriação que o sujeito faz da linguagem seria apenas um ato instrumental, de natureza linear colocando-a, portanto, a serviço de uma intenção: "Do ponto de vista do ator social que 'comunica', não existe nenhuma classe de indeterminação: ele sabe (ou crer saber) o que 'quer dizer' e, em função desta representação, produz o seu discurso." (Sigal; Veron, 2004, p. 19).

O conceito de enunciação é definido não pela complexidade intrínseca ao funcionamento da matéria significante, mas pela noção de intencionalidade, aspecto sobre o qual repousaria a completude. Esta questão é, emblematicamente, exemplificada pela matéria jornalística do correspondente do New York Times, no Brasil quando acusa o presidente Lula de hábitos alcoólicos. Ao defender-se, na Justiça, sobre a procedência da sua versão, o jornalista declara que " $O$ artigo limita-se apenas a veicular comentários, não contendo nenhum juízo de valor do próprio requerente" ${ }^{\prime \prime} \mathrm{Ou}$ seja, confessa a noção de linguagem apenas como um meio, ao 'desconhecer' que a construção do texto passa por complexas operações, pois é dele ${ }^{-}$enquanto enunciador ${ }^{-}$ao escutar pessoas (fontes) o selecionar materiais, extrair seus fragmentos e agrupá-los no seu próprio texto. Naturaliza seu trabalho, ao 'camuflar' seu processo produtivo. Esse tipo de enunciação contém uma racionalidade, assim definida:

É na relação de uma enunciação com as referências que toma em consideração implícita e explicitamente, para se enunciar, que vai se inscrever a pretensão de completude do sujeito da enunciação, uma vez que essas referências valem, para ele, como a realidade. (Flahault, 1979, p. 110).

Ao restringir a complexidade do processo enunciativo ao ato do 'sujeito falante', sugere-se que está na instância do próprio sujeito a possibilidade de tudo poder ser dito, uma vez que o mesmo deteria controle sobre o discurso que profere e os efeitos de sentidos por ele presumidos. Abstrai a existência de novos regimes e processos de discursividades, que neste novo quadro societário "devem ser entendidos enquanto sistemas complexos" (Veron, 2004, p. 83). A situação de comunicação se restringiria à própria cena, sem que processos mais complexos pudessem perturbar a sua constituição e seu funcionamento. A isso chamamos de 'enunciação como completude'.

\section{A enunciação e a incompletude}

A noção de trabalho da enunciação, distinta da concepção intencional, vem de um lingüista, Émile Benveniste. Fala-nos de um ato, ou seja: "A enunciação éo ato mesmo de produzir um enunciado e não o texto do enunciado (...) É este colocar a língua em funcionamento por um ato individual de utilização" (Benveniste, 1989, p. 80). Ato do sujeito que, ao transformar a língua em fala, nele inscreve-se, pois constrói a sua própria imagem e a imagem daquele de quem, ou a quem fala. Trata-se de um trabalho no qual o sujeito não goza de autonomia, uma vez que ao se apropriar da língua sofre destas 'injunções', condição que limitaria as possibilidades do seu ato enunciativo se desenvolver em torno de linearidades e de determinações. Ao inscrever se na ordem da linguagem, esta não pode servir o enunciador, de forma instrumental, segundo padrões de intencionalidade, uma vez que o ato de enunciação ${ }^{-}$o de natureza face-a-face e os outros mais complexos ${ }^{-}$tem "no centro uma relação de intersujeitos (...) relação de co-enunciação (...)" (Fischer 1991, p. 218).

Dinamizada pela relação de intersujeitos, a enunciação não dá conta da completude, do 'encarceramento' dos sentidos em suas fronteiras, uma vez que quando postos em funcionamento, os atos discursivos, ao se deslocarem de suas próprias fronteiras, instalam-se em 'zonas de pregnâncias', que geram novas enunciações e distintos efeitos de sentidos. No lugar do controle, a enunciação se desdobra em novos feixes de relações, com intervalos e defasagens. A enunciação (jornalística) de completude desconhece que o 'sujeito falante' está imerso em complexas relações e que opera, ao mesmo tempo, como emissor e receptor. E, assim, as condições de produção dos discursos são constituídas e atravessadas por múltiplas indeterminações. Daí, as transformações que têm ocorrido nas estratégias de 'contratos de leituras' dos mídias. Pensados como operação que instituem vínculos entre produção/recepção, através dos quais as práticas midiáticas promovem o deslocamento ${ }^{-}$ou reformulam o status da recepção ${ }^{-}$os 'contratos' transformam o lugar de operação de referência, pela emergência de operações de auto-referência. Ou, estabelecendo possibilidades para que receptores acedam aos processos produtivos de sentidos midiáticos, segundo estratégias nas quais são transformados em espécies de 'co-sujeitos' do ato discursivo. Os 'contratos', 
nas suas mais diferentes modalidades, são 'sintomas' que sinalizam as preocupações do âmbito da produção midiática em regular relações de defasagens (incompletudes) de sentidos com a recepção, na expectativa de, assim, reduzir as complexidades das interações.

Este conceito de enunciação apresenta-se como espécie de contrariedade ao 'paradigma consciencialista', e sobre o qual situa-se a noção de objetividade. Lembra que as operações do sujeito não se fazem no vazio: 'acomplam-se' e subordinam-se a complexos agenciamentos do aparelho da enunciação que, enquanto dispositivo "nada mais é do que a marcação da subjetividade na estrutura da língua" (Nascimento; Teixeira, 2005, p. 36).

Estas noções não foram pensadas por Benveniste tendo como objeto os discursos jornalísticos, mesmo que viessem indultamente a ensejar a abertura de longas perspectivas para análise complexa dos discursos (Benveniste, 1982, p. 88). Mas, ele situou a questão das discursividades num território de complexidades, retirando a problemática do sentido de uma consideração determinística. Suas reflexões repercutem sobre vários objetos, quando se põem " $\mathrm{em}$ contato com todas as práticas complexas de significação das quais se pode 'desimplificar-se' os funcionamentos de sentidos." (Fabbri, 1999, p. 50).

\section{A enunciação jornalística em dois "regimes" de sociedades}

As mudanças na enunciação jornalística, conforme aqui se propõe, não são apenas fenômenos estritos de linguagens, pois envolvem também dimensões situacionais, conforme sugere o próprio Benveniste: “ $\mathrm{Na}$ enunciação se considera o ato mesmo, as situações onde ele se realiza e os instrumentos de sua realização". (Benveniste, 1981, p. 81).

Levando-se em conta dimensões "macro-situacionais", parece interessante distinguir as características da enunciação jornalística na passagem de uma 'sociedade dos meios' para a 'sociedade da midiatização'.

Na primeira, as operações de enunciação dos discursos jornalísticos destacam-se por típica atividade de natureza representacional, uma vez que seu trabalho opera como um dispositivo de mediação. Suas operações enunciativas destacam o discurso com certo protagonismo, no papel de indicar a existência e funcionamento de outros campos sociais. O dispositivo, nesse estágio, está a 'serviço de contato'. Mas as marcas que tratariam de apontar a sua existência, tratam de mantê-lo opaco, talvez dissolvidas na condição de um 'dispositivo enunciativo de referência'. Ou seja, o dispositivo está preparado para realizar uma competência representacional.

A transição de uma 'sociedade a outra', em termos da natureza da enunciação jornalística, ocorre quando passam a ser explicitadas as marcas deste discurso. Os mídias são distinguidos, na expressão de Giddens $^{6}$, como uma 'porta de acesso' dos atores sociais ao mundo dos 'sistemas abstratos', pois a sua enunciação funciona como um evidente dispositivo-leitor. Neste momento, o trabalho midiático já começa a se investir de certa 'protagonização' voltada para a tessitura de um novo lugar, os primórdios do lugar de auto-refencialidade:

A necessidade de recuperar a materialidade dos processos significantes(...), não em seu caráter de transportadores de algum sentido que lhes é agregado - as mensagens(...) mas enquanto marca, modelo, matriz, racionalidade produtora e organizadora dos sentidos. (Mata, s/d, p. 84-85).

$\mathrm{Na}$ 'sociedade da midiatização' é o desenvolvimento de processos e protocolos de ordem sócio-técnica-discursiva, em função de novos mercados, inclusive discursivos, que vai redesenhando a questão dos vínculos sociais. Estes são submetidos a uma nova ambiência e cujo funcionamento decorre de novas estratégias enunciativas. Tecnologias são convertidas em meios de interação e redefinidoras de práticas sociais, ou incidem, diretamente, sobre os seus regimes de discursividades, submetendo diferentes campos sociais às novas lógicas e de processos de enunciabilidade. Neste novo cenário, instalam-se novas 'formas de contato'. Nele, os mídias não são apenas meios, mas complexos sistemas, enquanto lugar reguladores, que através de suas próprias auto-operações realizam o funcionamento de um novo tipo de trabalho do registro do simbólico ${ }^{7}$. A sua conversão em uma 'realidade própria', tem efeitos sobre sua autonomia como campo, bem como no seu próprio trabalho de enunciar realidades. Falar desta posição e nestas condições, implica, como 'efeito de sentido', falar visando 'completar simbolicamente o sujeito'. (Flahault, 1979). A autonomia em suas operações de referenciação, permite que este campo se torne intensa e, progressivamente, em uma realidade própria, aspecto que repercute também sobre as condições de produção do acontecimento. Este deixa de resultar de transações complexas, reunindo fontes-meios, e passa a depender mais de operações manejadas pelo próprio trabalho jornalístico. A realidade externa se faz presente, mas a partir de operações de acoplamentos feitas pela enunciação, que tratam de instituí-la em conformidade com as suas próprias regras e com suas gramáticas ${ }^{8}$.

\section{Leituras da Completude, ou quando "a linguagem come o real"9}

Distinto do ponto de vista segundo o qual, o sujeito controla o próprio discurso que profere, o trabalho jornalístico de engendramento de sentido reúne, pelo menos, três aspectos: a) as operações enunciativodiscursivas propriamente ditas; b) os produtos que resultam destas operações, no caso os textos; c) e as representações que deles se fazem, a partir do momento em que são colocados no circuito da circulação 


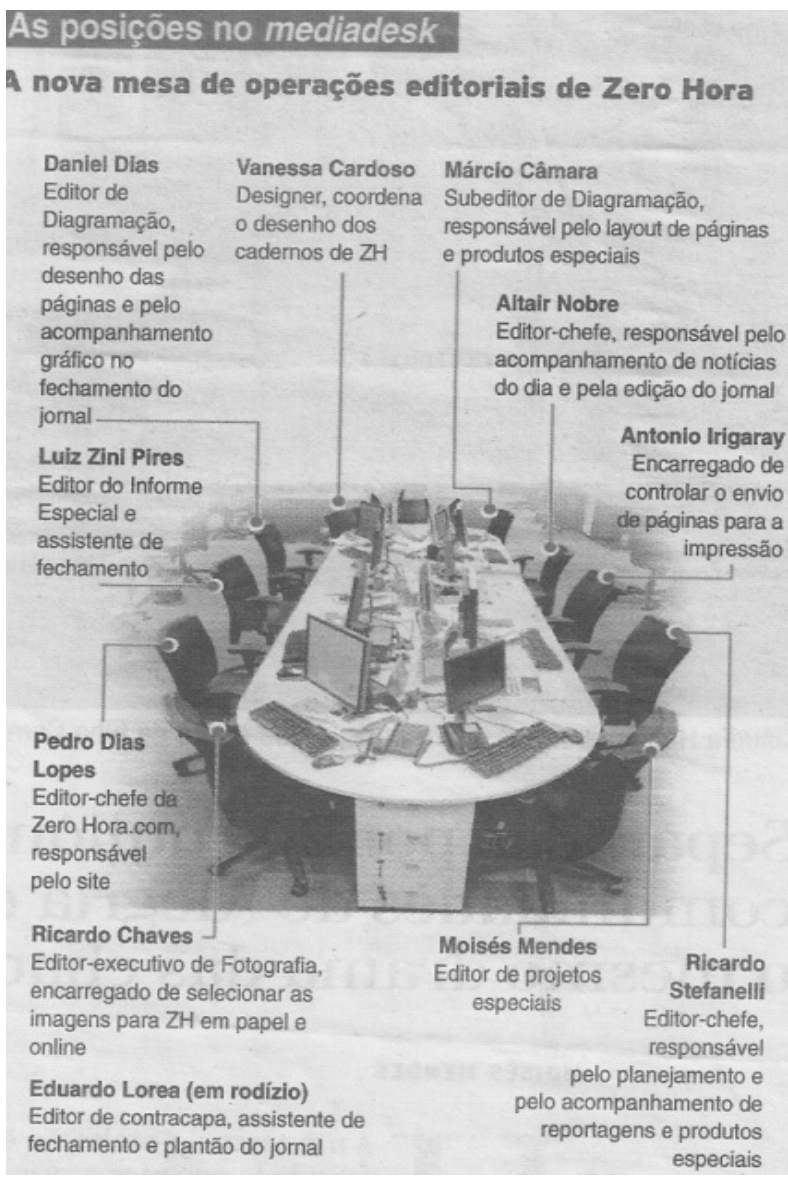

social, enquanto possibilidades de efeitos ${ }^{10}$. Tais dimensões - operações, textos e representações - envolvem níveis de muitas complexidades, que estão subordinadas às condições de produção, de circulação e de reconhecimento, que envolvem não só elementos da matéria significante, mas as características de sociedade em que estes processos funcionam. Considerando estes três momentos, examina-se alguns fragmentos de discursos que se estruturam no interior de práticas discursivas jornalísticas e que são fortemente atravessadas por estratégias de auto-referência e nas quais engendram-se e intensificam-se os 'efeitos de sentido' da 'completude'. Uma observação de ordem empírica: práticas de auto-referencialidade no âmbito do discurso jornalístico ocorrem em distintos cenários, como, por exemplo, na Espanha. Lá as manifestações de auto-referencialidade dão ênfase a processos de auto-promoções, pois os jornais dão a conhecer os seus produtos editoriais (suplementos, cadernos, etc.), operação que não serve a interesses especificamente informativos. Algo distinto do que ocorre no jornalismo brasileiro, onde o trabalho de auto-referência chama atenção para o próprio processo produtivo da informação (Duran, 2006) A enunciação chama atenção para o 'modo de fazer o acontecimento'.

\section{Apresentando o ambiente}

Neste item, chama-se atenção para três operações de auto-referência sobre diferentes 'modos de existência' do ambiente jornalístico. A primeira mostra-o não como realidade distante, mas como território que pode ser compartilhado e vivenciado pelo leitor. Não se trata de dar referência sobre onde 'vivem' os jornalistas, mas trazer o leitor para seu interior, provando que as realidades de um e de outro, não são distintas. Esta operação se faz no contato, do dia-a-dia, na interação jornal-leitor.

A coluna 'Cartas do Editor' apresenta imagem sobre o novo ambiente da redação de $\mathrm{ZH}$ (mediadesk), em que detalha o funcionamento de sua dinâmica e dos seus atores, animados por gráficos, setas e um texto em que descreve ao leitor como percorrer o ambiente. Lembra ainda: "Muito mais que uma mudança física, o mediadesk de Zero Hora ${ }^{-}$um dos primeiros do Brasil ${ }^{-}$é resultado de uma profunda alteração no modo de se fazer jornalismo" (Zero Hora, p. 2, 23/09/2007).

A segunda, enfatiza o funcionamento do discurso a partir do ambiente. Define-se como 'o debate antecipado'. Debates políticos são promovidos pelas redes de televisão e são também objeto de propaganda institucional dos seus realizadores, onde as emissoras duelam, através de operações de auto-referência, no espaço publicitário. Argumentam sobre as virtudes dos formatos, chamando atenção para cada de uma de suas estratégias sobre a cobertura das eleições. Ao anunciar o seu debate, a Rede Globo dizia: "EU PRO$\mathrm{METO}^{\prime \prime 1}$, mensagem respondida um dia depois pela Bandeirantes, no mesmo jornal e com a mesma disposição gráfica: "ELES PROMETEM, a BAND CUMPRE"12

Na véspera (26/10/2006) da realização do seu debate, a Rede Globo destaca ampla matéria no 'Jornal Nacional', em que descreve não a importância do debate, mas as operações que envolvem a sua produção.

Para receber os candidatos, carpete azul. Foram usados 1,5 metros quadrados para forra o estúdio (...) Quase cem pessoas ocuparam o estúdio, trabalhando em ritmo acelerado. Gente que tem noção da importância do que vai acontecer amanhã (...) Um pequeno monitor, sensível ao toque, vai selecionar perguntas feitas por eleitores que ainda não sabem em que vai votar para presidente.(...) Os 80 eleitores indecisos (...) vão se sentar em arquibancadas à direita e à esquerda do mediador (...) E 12 deles farão perguntas, que serão transmitidas por um telão (...) Os candidatos (...) poderão circular à vontade.

Em seu site, na semana que antecede o debate, insere através de uma animação infográfica, a mensagem: 'Conheça os detalhes do último debate'. Anuncia as características do ambiente de sua realização; descreve as regras do debate; a posição dos personagens; os fluxos de interação entre apresentador, candidatospresidenciáveis e público convidado (eleitores indecisos); o uso de processos eletrônicos, etc. Tem-se operação de co-referência (telejornal+site). No ciberespaço, descreve-se as condições nas quais o acontecimento 


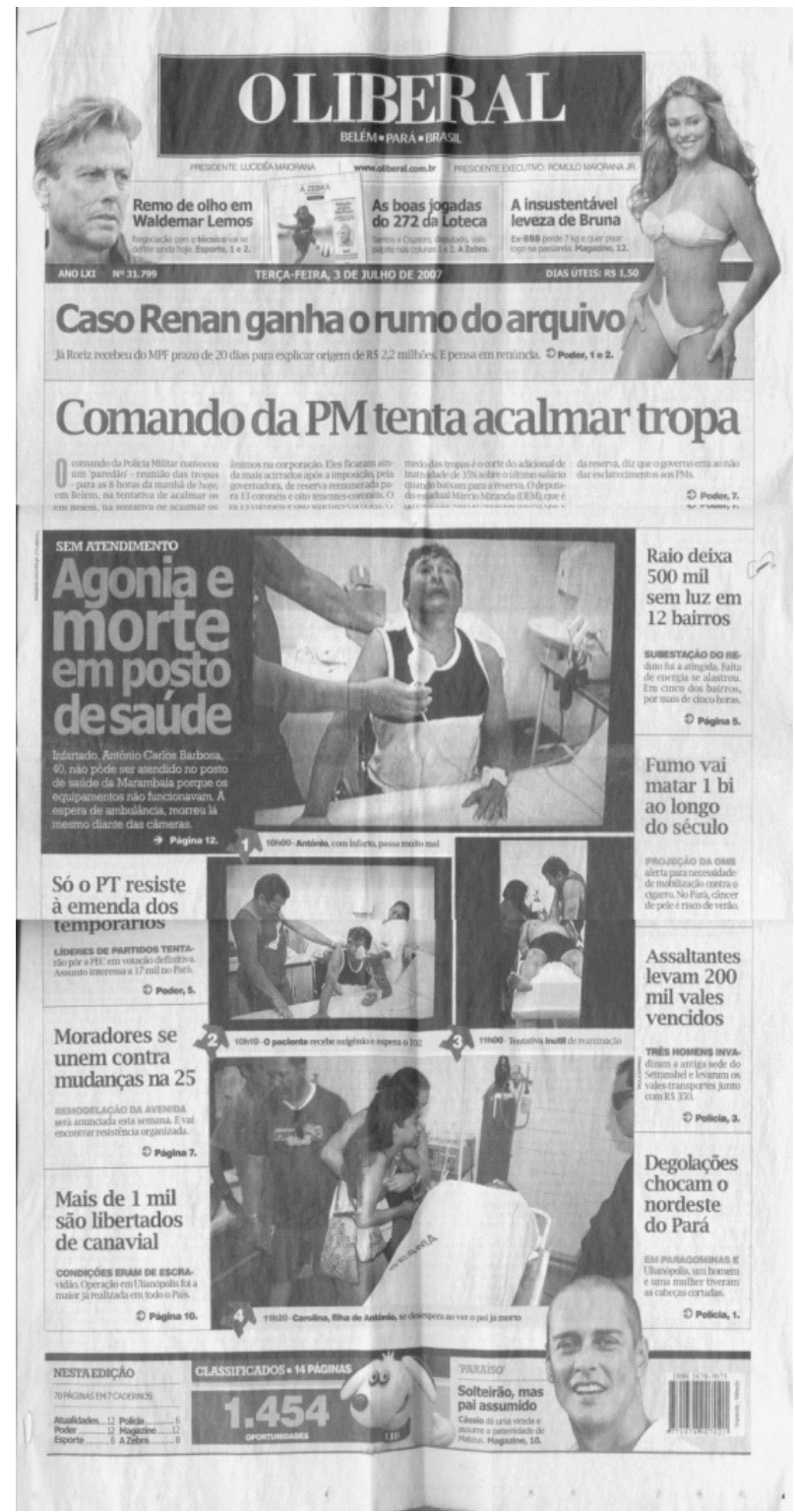

se faria, algo totalmente atípico em relação à natureza da enunciação do discurso político quando produzido pelo discurso telemidiático. As enunciações coreferem, em níveis diferentes, o próprio processo produtivo do acontecimento, situando-o em duas temporalidades: a que aponta para as regras e a que descreve o processo produtivo. Mas, ambas chamam atenção sobre a capacidade do dispositivo televisivo em engendrar $\mathrm{o}$ acontecimento.

A terceira operação, "Nada pode sobrar...", descreve não mais a constituição e as indicações sobre o funcionamento do ambiente, mas sua ação propriamente dita. A descrição sobre as operações e o modo como interfere sobre o acontecimento, passa de uma posição narrativa, para aquela de intervenção.

Durante a Copa do Mundo de 2007, a Rede Globo introduziu nas suas transmissões esportivas a mediação de um especialista em fonoaudiologia que fornecia elementos sobre os diálogos entre treinador e jogador, que não poderiam ser captados à distância pelos narradores. Esse tipo de intervenção, estranho à nar- rativa esportiva midiática é exaltado pela própria tv, no Fantástico (18/06/2006), que numa operação coreferencial, sublinhava: "Nada escapa às câmeras atentas da Copa do Mundo. Uma conversa entre jogador e técnico ou uma discussão no meio de campo. O que eles dizem no calor da partida? Para matar essa curiosidade, o Fantástico procurou uma fonoaudióloga e 4 adolescentes surdos."

Comentando a reação do técnico da seleção brasileira sobre apropriação, a própria Rede Globo, no Jornal Nacional (26/06/2006), 'contra ataca' justificando a operação: "Parreira diz que ficou triste e desapontado com o 'quadro Leitura labial e considera que teve a privacidade invadida'. Quando soube das declarações de Parreira, a direção do Fantástico lamentou (...) porque o considera um dos momentos mais bem humorados do programa, um quadro que se encaixa mais no entretenimento do que no jornalismo" (...) "[o Programa] só foi o ar porque teve a certeza de que os espectadores saberiam compreender as circunstâncias." Ao buscar a captação do que estava 'faltando' na transmissão, o dispositivo lembra que nada pode sobrar no seu trabalho de busca do real. Para tanto, busca ainda a cumplicidade do leitor, pois dele recebe fiança para fazer a 'captura das sobras'.

\section{A morte desdobrada em tempos descontínuos}

As condições de cobertura da morte de um trabalhador, em posto de saúde em Belém (julho de 2007), chamam atenção pela natureza das operações enunciativas que, trabalhando temporalidades distintas, repercutem sobre a própria noção de 'testemunhalidade midiática'.

Apresentando insuficiência cardíaca, o paciente morre em conseqüência de falha nos serviços de atendimento. Sua hospitalização e morte se tecem diante da 'monitoração' midiática, numa espécie de 'relato ao vivo', de uma morte que se consome. Ou, apontando para um certo 'modo de morrer'. A TV cobre em tempo real, gerando imagens. Os jornais mostram, na edição do dia seguinte, sua cobertura apoiada na captura da tevê, apresentando marcas do seu 'processo de apuração' fotográfica.

A televisão, além de anunciar, co-determina parte do 'modo de morrer' de Antônio, pois transforma a morte no 'caso Antonio Barbosa', que exige complexas co-determinações. Quando a enuncia, o jornal refere-se ao registro da temporalidade televisiva, onde está a gênese do registro: "TV registra morte de homem". E explica: "A TV Liberal levou ao ar as imagens dos últimos momentos de vida do segurança Antônio Carlos Barbosa no posto de saúde" (Amazônia, p.1. Belém, 03/07/ 2007). Dá o crédito, à operação televisiva, enfatizando o seu lugar de testemunhalidade, sublinhando a performance da sua enunciação: 'os últimos momentos' de Antônio. Além do crédito, explicita a 'pista' ${ }^{-}$enquanto registro ${ }^{-}$que co-valida a sua operação enunciativa de segunda mão, ao fotografar as imagens a partir do enquadramento televisivo. A matéria de $1^{\mathrm{a}}$ página, vem contaminada com elementos da enunciação visual: as imagens capturadas são diagrama- 
das, na forma de uma ampla 'foto-seqüência' ${ }^{-}$quatro unidades articuladas entre si. Cada uma traz um 'selo' indicando a hora em que foi capturada, registro que se reporta também a momentos recortados, pela enunciação, ao próprio tempo de sofrimento do paciente. As fotos são co-referidas por legendas, no tempo presente, aspecto que indica marcas da intervenção jornalística sobre o registro da TV, através de quatro momentos: "Imagem 1: 10h - Antônio, com infarto passa mal"; "Imagem 2: $10 h 10$ - O paciente recebe oxigênio e espera o 192"; "Imagem 3: 11h - Tentativa inútil de reanimação"; "Imagem 4:11h20 - Carolina, filha de Antônio, se desespera ao ver o pai morto."

Estas operações mostram complexas enunciações que envolvem a construção do acontecimento, a partir de co-determinações de enunciações midiáticas. São produzidas e geram temporalidades distintas, sugerindo, enquanto leitura, que o fato se faz em meio ao efeito das diferenças enunciativas. Tais descontinuidades visam lembrar que o 'tempo da enunciação' se sobrepõe ao do fato, e se desdobra através dos regimes de discursividades das diferentes mídias. Como vimos, TV e jornal produzem, por tempos distintos de fabricação, acontecimentos diferentes. O real, quando submetido a regimes de simbolização desdobra-se em realidades construídas, cujas operações de produção tratam de singularizá-lo à própria enunciação de cada um dos dispositivos. Assim, os sentidos restam sem manejos. E os regimes de discursividades midiáticos encadeiam os processos de enquadrar os sentidos em distintas enunciações e respectivas temporalidades, para não deixá-los escapar. Quem valida os 'últimos momentos' de Antônio: as imagens ou as fotos-legendas?

\section{A guisa de conclusão (A incompletude da enunciação. Ou lembranças sobre as sobras...)}

Vem de uma operação de co-referência enunciativa o registro de que a incompletude resiste às operações enunciativas. É descrita no seio de uma espécie de um trabalho 'analítico-semiológico', status que se pode atribuir à coluna do Ombudsman, da Folha de São Paulo.

Numa espécie de leitura de 'contramão' às convicções enunciativas da completude, a coluna critica o uso da fotografia a serviço da noção da objetividade, sobre a qual residiria a pretensão de completude do enunciador. Ao comentar o processo de edição das fotografias do senador Renan Calheiros, critica tanto os propósitos dos editores-jornalistas quanto os do manual de redação para quem: "A maneira mais convencional e acomodada de encarar a fotografia é tratá-la como mero complemento da informação escrita. (...) O recurso visual do jornalismo impresso moderno deve ser entendido como uma possibilidade (...) suplementar à informação textual." (FSP, Ilusão de ótica, 16/09/2007).

Segundo o ombudsman, as fotos visam instituir o ponto de vista através de metáfora visual que mostra o senador abandonado. Capturado sozinho, ou mesmo ao lado de pessoas, mas segundo o enquadramen-

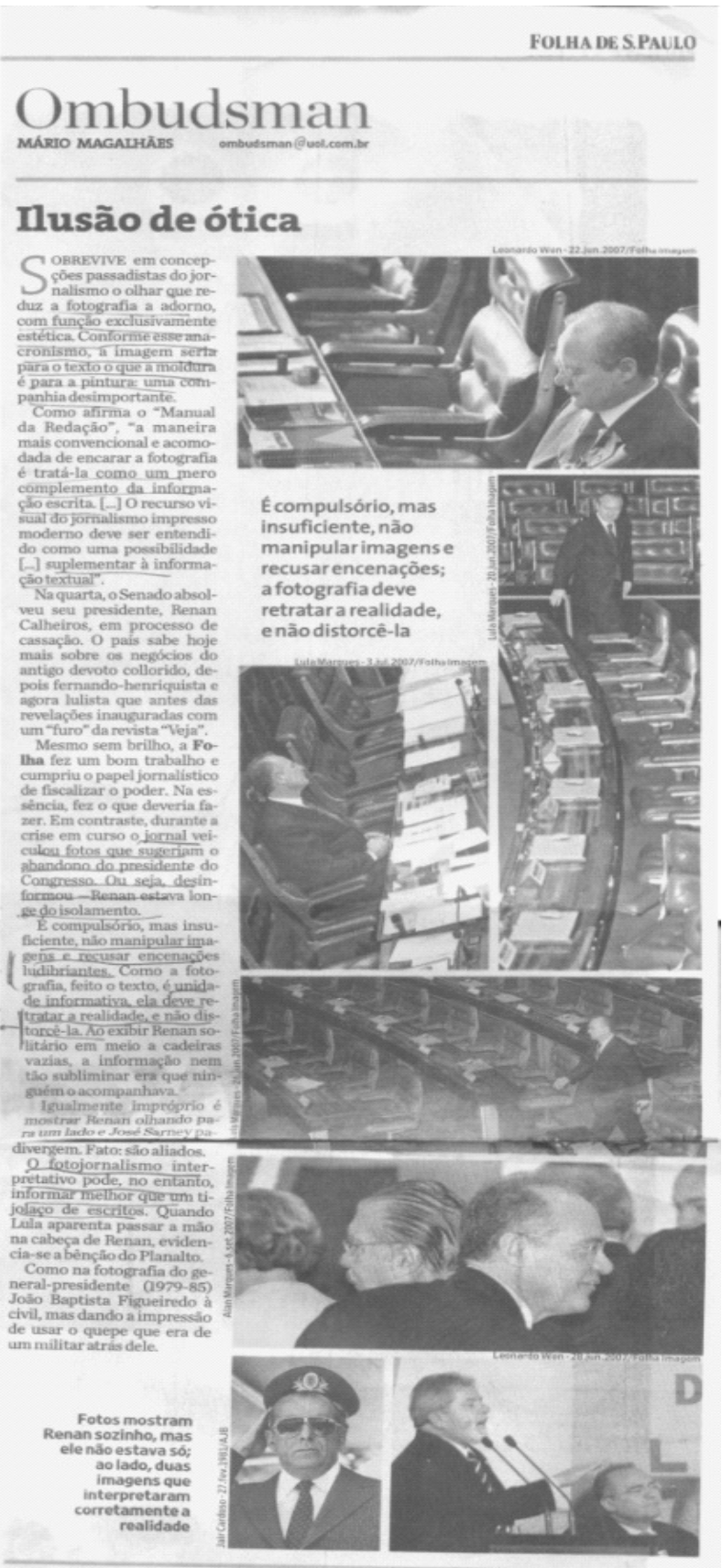

to fotográfico, mostradas indiferentes à Renan. Nas fotos ${ }^{-}$co-referidas por legendas ${ }^{-}$Calheiros é um ator abandonado. Ali, marcas de um corpo ${ }^{-}$objeto $^{-}$que flutua destituído de amparos. Não se trata da 'solidão do poder', mas daquela que é engendrada pela operação jornalística.

A estratégia desmontada pelo 'jornalista-leitor' critica os princípios de constituição do acontecimento explicitando no âmbito do discurso jornalístico os limites de uma operação que dissimula o que pretende apontar, mas que permanece passando 'incólume' à determinação da noção de objetividade. A lógica da objetividade trata de velar a linguagem, esvaziando o seu poder de sentido, apagando as motivações sobre as quais desenvolvem as estratégias e buscando dissolver a astúcia de suas operações. Mas o que é forte nessas, se presentifica através de pormenores e que 
são re-mobilizados por uma outra estratégia de leitura quando o ombudsman lembra e restitui o que a manobra camufla ou dissolve. Este 'leitor' diz que alguma coisa 'sobra' nesta operação de co-edição de imagens-textos. É é na recuperação da sua leitura que residem os sentidos velados... Sentidos restituídos numa outra operação enunciativa que não mostra mais a operação da cena, mas aquelas que a desmonta e a sua própria inteligibilidade.

$\mathrm{Na}$ 'sociedade dos meios' estes tratam de 'apagar' ou deixar opacas as marcas de suas operações de referência. Em tempos da midiatização fazem algo mais: explicitam essas marcas, chamando atenção para 'regras privadas' que constituem cada sistema jornalístico de produção de sentidos, enquanto não só uma espécie de 'ator interpretativo', mas como o elemento que é convertido no próprio acontecimento. O acontecimento reside na própria existência do dispositivo que o engendra e o põe em funcionamento.

Talvez devêssemos indagar por que a enunciação midiática se transforma no próprio acontecimento, encerrando nas suas fronteiras as potencialidades dos sentidos?

A enunciação jornalística apóia-se em não defasagens. Mas como se sabe, o seu trabalho enunciativo é ligado ao tempo da fala, que rege e cadencia outras temporalidades e processos que fazem agir os enunciadores, enquanto habitantes da ordem das interdiscursividades. Tal diversidade que marca a enunciação, é chave para se compreender a incompletude da enunciação jornalística, uma vez que as possibilidades instauradoras de inteligibilidades são engendradas em meio a intervalos e aos compassos de temporalidades distintas. Nestas condições, como diz Benveniste ${ }^{13}$, o tempo do discurso funciona como um tempo de intersubjetividade (1985, p. 69). Significa que o trabalho discursivo, 'habitante de fronteiras' ou caminhante nas 'zonas de pregnâncias', está sempre submetido às intempéries de uma 'desarticulação estrutural'.

Essas questões nos fazem pensar que as condições de enunciação impõem à autonomia da midiatização alguns limites, tornando-a relativa. Sem dúvida, suas marcas inscrevem-se cada vez mais em produção, em circulação e em recepção. O que não significa dizer que se consumam em processos lineares. No lugar deles, incompletudes que também se inscrevem nas cenas enunciativas jornalísticas e na relação destas com a sociedade.

A leitura do ombudsman presentifica a lembrança de permanência dos intervalos nos processos enunciativos internos ao jornalismo, quando aponta as incompletudes de suas operações e dos ideais da própria cultura jornalística. Denuncia sobras que resultam de completudes e que não podem estar atentas às perturbações de sentidos outros que habitam essas sobras ${ }^{-}$relação foto/imagem. Vale registrar que sua manifestação sobre a incompletude do trabalho da enunciação é reiterada pelo 'olho' da coluna que ex- plicita, entre as fotos, fragmento 'perdido' no próprio trabalho analítico da leitura do ombudsman: "É compulsório, mas insuficiente, não manipular imagens e recusar encenações; a fotografia deve retratar realidades e não distorcê-la." (Mário Magalhães)

Impõe-se à autonomia intensiva do campo midiático uma contradição: de um lado, expansão de suas fronteiras, através da homogeneidade dos processos de produção de sentidos, e conseqüentes processos de afetação junto a outras práticas sociais; de outro lado, a heterogeneidade dos atores e dos processos de recepção, pela transformação de massas/públicos/ multidões em indivíduos sozinhos ou nas aglomerações momentâneas. Essa dualidade constitui uma defasagem, colocando em questão a qualidade dos vínculos que reúnem estruturas de produção/reconhecimento de sentidos. Não mais reunidas segundo estratégias que os vinculava, conforme a teoria da comunicação funcionalista, tais relações se vêem constituídas por muitos desvios, pontos de fuga, indeterminações, etc, produzindo, inclusive, a emergência do 'homem ordinário' à cena da invenção dos sentidos. Nesta ruptura de contato, emerge o trabalho da auto-referencialidade como possibilidade de instituir um novo vínculo com o leitor, na medida em que o mesmo é convertido pelo contrato na condição de um novo sujeito interpretativo. Vem jogar o jogo ${ }^{-}$e os 'contratos' estão aí para falar deste deslocamento. Porém, quem detém as regras interacionais desse processo é o dispositivo da produção.

Permanecemos no seio da 'enunciação da completude', pois nas regras em que o jogo é praticado, visase evitar que o sentido derive. O leitor lê, mas é a estratégia auto-referencial da enunciação jornalística que faz a 'primeira leitura'.

O que fazemos destas operações de completude, enquanto efeitos, pouco sabemos ainda, especialmente dos seus possíveis desencontros e incompatibilidades, quando apropriadas pelos atores dos campos sociais. Mas, devemos priorizar, via processos observacionais, o funcionamento da midiatização em suas diferentes dimensões, especialmente no âmbito das práticas sócio-discursivas, na medida em que a midiatização continua a se inscrever nos processos sociais. Mergulhar na descrição dessas complexas operações pode proporcionar novas hipóteses de investigação mediadas por angulações, aquelas do trabalho empírico, que nos ajudam a aprofundar a hipótese de que a midiatização supõe resolver a questão da incompletude dos sentidos. mfamecos

\section{NOTAS}

1. LASCH, Scott. Critica de la informacion. Buenos Aires: Amorrortu, 2004.

2. Rede Prosul de Pesquisa - Comunicação: sentido e sociedade. Implicações dos meios de comunicação nas transformações das práticas sociais na Améri- 
ca Latina. Seminário Midiatização: sociedade e sentido. São Leopoldo/RS, 10 a 13 de outubro de 2007.

3. Ver: FAUSTO NETO, Antônio. Lula presidente televisão e política na campanha presidencial. São Leopoldo/São Paulo: Unisinos/Hacker, 2003.

Ensinando à televisão. João Pessoa: Editora Universitária, 2001. —. A Igreja doméstica. In: IHU OnLine. São Leopoldo: Unisinos, 2004. —_. A midiatização jornalística do dinheiro apreendido: Das fotos furtadas à fita leitora. In: Comunicação: Veredas - Revista de Pós-Graduação em Comunicação da Universidade de Marília. v. 1, ano 6, nº 6, São Paulo, 2007. —_. Será que ele é? Onde estamos? Reflexões sobre a mediatização de um discurso proibido. In: Ícone. Recife, 2006. p.41-60

4. FAUSTO NETO, Antônio. O jornalismo e os limites da representação. In: Caleidoscópio - Territórios do Jornalismo. N. 5/6 Lisboa: Universidade Lusófona. Lisboa, 2004/2005.

5. FAUSTO NETO, Antônio. O jornalismo e os limites da representação. In: Caleidoscópio - Territórios do Jornalismo. N. 5/6 Lisboa: Universidade Lusófona. Lisboa, 2004/2005.

6. GIDDENS, Anthony. As conseqüências da modernidade. São Paulo: Editora da UNESP. 1991.

7. LUHMANN, Niklas. A realidade dos meios de comunicação. São Paulo: Paulus, 2005.

8. Estas considerações sobre as distinções entre 'sociedades dos meios' e 'sociedade midiatização' estão discutidas na obra El Cuerpo de las Imágenes, de Eliseo Verón. (Norma, Buenos Aires, 2004).

9. LACAN, Jacques. O sintoma - Seminário 23. Rio de Janeiro: Jorge Zahar, 2007. p.31

10. Considerações sobre esta démarche estão situadas em VERON, Eliseo. A produção do sentido. São Paulo: Cultrix, 1980.

11. O Estado de São Paulo, p. A 27, 30/07, São Paulo/ Brasil.

12. O Estado de São Paulo, p. B 9, 31/07, São Paulo/ Brasil.

13. BENVENISTE, E. Problémes de Lingüistique Générale. Tomo 1. Paris: Gallimard, 1980. p.69

\section{REFERÊNCIAS}

BARTHES, Roland. Variaciones sobre la escritura. Buenos Aires: Paidós Comunicación 2002.
BENVENISTE, Emile. Problemas de Lingüística Geral. Campinas: Pontes, 1989.

BENVENISTE, Emile. Problémes de Lingüistique Générale. Paris: Gallimard, 1980.

DURÁN, Marina S. La autorreferencia como estratégia de promoción: periodismo o publicidad. In: Zer. N.20. Madri, 2006. p.197-209

FABBRI, Paolo. El giro semiótico. Barcelona: Gedisa, 1999.

FAUSTO NETO, Antônio. O discurso político entre recusas e controles das estratégias enunciativas midiáticas: observações sobre a midiatização da campanha eleitoral de 2006. In: Galáxia. São Paulo: PUC/SP, 2006.

—. Da 'construção da realidade' à 'realidade da construção' . In: Edição em Jornalismo - Ensino, Teoria e Prática. Santa Cruz do Sul: EDUNISC, 2006.

. O jornalismo e os limites da representação. In: Caleidoscópio - Territórios do Jornalismo. N. 5/6 Lisboa: Universidade Lusófona. Lisboa, 2004/ 2005.

FISCHER, Sofia. Le détour des chemins. In: La théorie de Antoine Culioli - Ouvertures et Incidences. Paris: Orphys 1991.

FLAHAULT, François. A Fala Intermediária. Lisboa: Via Editora, 1979.

FLORES, Valdir do Nascimento; TEIXEIRA, Marlene. Introdução à lingüística da Enunciação. São Paulo: Contexto, 2005.

MATA, Maria Cristina da. De la cultura masiva a la cultura mediática. In: Diálogos de la comunicación. Lima: Felafacs, s/d. p.80-91

SIGAL, Lígia; VERÓN, Eliseo. Perón o Muerte. Buenos Aires: Eudeba, 2004.

STEIMBERG, Oscar; TRAVERSA, Oscar. Estilo de época y comunicación mediática. Tomo I. Buenos Aires: Atuel, 1997.

VERÓN, Eliseo. Fragmentos de um tecido. São Leopoldo: Unisinos, 2004.

VERÓN, Eliseo. El Cuerpo de las Imagénes. Buenos Aires: Norma , 2004

LUHMANN, Niklas. A Realidade dos Meios de Comunicação. São Paulo: Paulus, 2005. 